\title{
Changes in the law on drinking and driving
}

\author{
J D J HAVARD
}

New legislation aimed at reducing the number of accidents caused by drinking drivers will take effect on 6 May. ${ }^{1}$ The extent to which drivers have been able to avoid conviction of the offence by relying on some technicality, or by taking deliberate steps to circumvent it, has been one of the most depressing aspects of our attempts to deal with the problem. The new law will go some way, but by no means all the way, to closing these loopholes. Drivers will no longer be able to avoid conviction for a section 5 offence (driving under the influence of drink or drugs) by running away from the vehicle, and the police will be able to enter any place where he has taken refuge if they have reason to believe that such an offence has been committed.

The section 6 offence (driving in excess of the prescribed limit) has been extended to cover those who have been "in charge" or have been driving a vehicle. The suspect has a defence, however, if he can satisfy the court that he never intended to drive when he was "in charge."

The "hip flask" device-for example, deliberately drinking after an accident in order to make it impossible to determine accurately the concentration of alcohol at the time of the accident-has been dealt with in respect of both section 5 and section 6 offences. Not only will the suspect have to prove that he took alcohol after the incident and before providing a specimen, but the onus is placed on the driver to show that he would not have exceeded the prescribed limit $(80 \mathrm{mg} / 100 \mathrm{ml})$ without the additional alcohol-thereby letting in the scientifically suspect practice of back calculation that is so widespread in European courts.

\section{Quantitative breath instruments}

What will attract the greatest public interest is the introduction of quantitative breath instruments. The police are no longer required to arrest the driver after a positive roadside test (or failure to provide one) in cases where the driver is prepared to go voluntarily to the police station. But in cases where there has been an accident resulting in injury to a third party the police may now enter any place-by force if necessary-to which the driver may have gone in order to obtain a breath test.

At the police station the lowest of two readings on the quantitative breath instrument will be taken for evidentiary purposes, but the driver will be allowed to opt for a confirmatory blood or urine sample to be taken (the choice of which will be left to the police) in cases where the lower reading is below $50 \mu \mathrm{g}$ (equivalent to $115 \mathrm{mg} / 100 \mathrm{ml}$ blood). Fewer than $5 \%$ of suspects are expected to be between 35 and $50 \mu \mathrm{g}$. In certain cases-for example, inability to provide the required two litres of breath-the suspect will be required to provide a sample of breath or of blood.

The new instruments will be carefully monitored, and simulated breath will be passed through the instrument both before and after each suspect is tested. The British Calibration Service, which has over 100 laboratories, will be responsible for routine checking of instruments.

From the medical point of view the most interesting provisions are those concerned with problem drinkers and alcoholics. Even with the current deplorably low level of enforcement,

British Medical Association, BMA House, Tavistock Square, London WC1H 9JP

J D J HAVARD, MA, MD, secretary more than 57000 drivers were found to be in excess of $80 \mathrm{mg} /$ $100 \mathrm{ml}$ (blood) in 1981 and well over half of these exceeded twice the limit. More than $\mathbf{3 0 0 0}$ drivers are found to have been disqualified twice within 10 years with blood alcohol concentrations over $200 \mathrm{mg} / 100 \mathrm{ml}$. In future, cases that exceed $150 \mathrm{mg} / 100 \mathrm{ml}$ will be notified to the Driver and Vehicle Licensing Centre at Swansea, where a record will be kept of all those falling within the high risk group-that is, those disqualified twice within 10 years with a blood alcohol concentration of more than $200 \mathrm{mg} / 100 \mathrm{ml}$, those disqualified once over $200 \mathrm{mg}$ and once for refusing to give a specimen, and those disqualified twice for failing to provide a specimen if there are reasonable grounds for suspecting an alcohol problem. After a second conviction the driver will be told by the Driver and Vehicle Licensing Centre that his convictions may be regarded as indicating a disability and that evidence may be required that his drinking problem is under control before his licence is returned to him at the end of the period of disqualification.

Special examination centres will be established in various parts of the country at which such drivers will be required to attend before the period of disqualification has expired. A structured interview and full medical examination will take place in each case, including specific blood tests. Doubtful cases will be referred to a psychiatrist with special interest in alcohol problems. The driver will have the same right of appeal to the court against refusal to grant a licence as he does against refusal based on other reasons.

These measures represent an important step forward. Much will depend on the attitude of the courts, and it must be admitted that the drinking driving cases have shown our adversarial

continued on page 1456

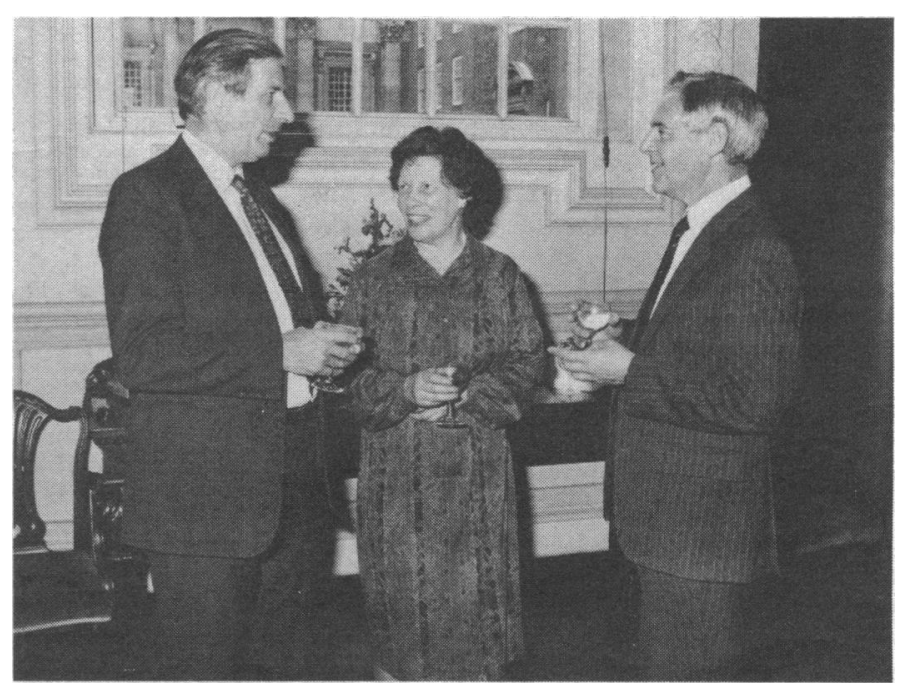

A well known figure at the BMA's annual representative meetings retired this month after 37 years with the association. Miss Barbara Middlemiss has been concerned with the organisation of annual and clinical meetings since the 1948 meeting in Cambridge. These have included several overseas meetings, including the successful clinical meetings in Hong Kong in 1979 and in San Diego in 1981. After the Hong Kong meeting she was presented with an award from the Hong Kong Tourist Association for her "outstanding contribution to the development of travel to Hong Kong." Last week Miss Middlemiss was presented with a carriage clock and a cheque from her colleagues by Dr John Havard (left), and a cheque from members of the representative body by Dr John Marks, chairman of the representative body (right). 


\section{GMS Committee: April meeting}

The General Medical Services Committee, which met on 21 April with Dr John Ball in the chair, expressed concern at the very smal number of general practitioners on the General Medical Council who are actively engaged in National Health Service practice. It was therefore decided to set up a small working party to examine the position leading up to the 1984 GMC election. The committee wants to ensure that local medical committees will seek out suitable people to sit on the GMC and that general practitioner votes for the candidates will be actively sought.

\section{Partnership agreements}

The committee has adopted the following statement, which will be reproduced in its advice on partnership agreements:

"If an incoming partner is to be a full sharing partner, then his share is normally calculated as a percentage of the profits of the firm and accordingly before the net profits of the firm are divided between the partners, the expenses of the firm are paid by the firm. The effect of this is that each partner notionally pays proportion of those expenses to the sam percentage as he receives a share in profits. As his share in profits varies so does his share of the expenses.

"If an existing partner is the owner of practice premises, he is perfectly entitled to charge the market rent to the partnership and it is desirable that this should be calculated by an independent valuer if the valuation of the district valuer is considered to be too low. If the 'valuation' in rental terms of the premises is higher than the market value, this means that the owner of the practice premises is receiving a payment which does not reflect market values and such excess receipt could be regarded as a receipt in exchange for the transfer of goodwill. In some partnerships, as a matter of concession by the owner of the premises, the only 'rent' charged to the practice is the amount of the district valuer's calculation. This has the advantage of simplicity and is also in some cases a recognition by the older partner of the committees. April 1983.

New fees problems of the younger partner coming into the practice with a smaller share of profits and the high outgoings of a young family."

In his opening remarks $\mathrm{Dr}$ Ball referred to the code of practice for clinical trials in general practice (16 April, p 1295). He hoped that doctors would participate in trials within the framework of the code. The chairman drew attention to the Home Secretary's decision that medical records should be excluded from the Police and Criminal Evidence Bill (23 April, p 1372). This was a considerable victory for the $\mathrm{BMA}$, he said, and he thanked those members who had written to their members of parliament on the subject. Another success had been achieved in the Health and Social Services and Social Security Adjudications Bill, which is at present in the committee stage in the House of Commons. As a result of efforts by the BMA and other organisations, the Bill no longe contained provision for the Secretary of State to appoint vice chairmen of family practitioner

A full report of the day's proceedings will be published in a future issue.

\section{Transnational postgraduate specialist training}

\section{EEC pilot project}

The Standing Committee of Doctors of the EEC is organising a pilot project for transnational postgraduate specialist training, which $\mathbb{\infty}$ will be coordinated by the Danish Medical o Association. Participants in the project should $\varrho$ be in their last or next to last year of specialist training (as defined in Directives $75 / 362$ and $\vec{F}$ 75/363) and must be proficient in the language of the country they are intending to work in. The BMA is also collating the names of hospital departments that are able to supply the necessary paid position for a six month or one $\stackrel{\mathbb{Q}}{\varrho}$ year period. Potential trainees and interested departments should contact, before 16 May,

CP Pilot European Training Programme Office,

c/o Danish Medical Association,

Attn T Kennedy,

Trondhjemsgade 9 ,

2100 Copenhagen $\varnothing$

Denmark.

Before accepting any position in the project $\stackrel{\sigma}{\omega}$ potential trainees are urged to contact their of postgraduate dean for advice.

\section{New fees for colliery emergencies}

The BMA has reached agreement with the National Coal Board on fees for attending emergencies at collieries, with effect from 1

\begin{tabular}{|c|c|c|}
\hline & $\begin{array}{l}\text { Old fee } \\
(\mathscr{L})\end{array}$ & $\begin{array}{l}\text { New fee } \\
(\mathscr{L})\end{array}$ \\
\hline \multicolumn{3}{|l|}{ Surface: } \\
\hline $\begin{array}{l}\text { Day visit }(8 \mathrm{am} \text { to } 8 \mathrm{pm}) \\
\text { Night visit }(8 \mathrm{pm} \text { to } 8 \mathrm{am})\end{array}$ & $\begin{array}{l}19 \\
34\end{array}$ & $\begin{array}{l}20 \\
36\end{array}$ \\
\hline \multicolumn{3}{|l|}{ Underground: } \\
\hline $\begin{array}{l}\text { First hour and a half } \\
\text { Subsequent hour or part } \\
\text { thereof }\end{array}$ & $\begin{array}{l}46 \\
17\end{array}$ & 48 \\
\hline
\end{tabular}

The National Coal Board has agreed to pay $\overrightarrow{0}$ $£ 13$ for a full medical examination (and report) by a person's general practitioner; $£ 18.50$, $£ 27$, or $£ 43$ according to the time taken for an examination and report by an independent doctor; and $£ 7.70$ for a short examination or report based on medical records. These fees are $\triangleq$ in line with fees paid by central government $\stackrel{\mathcal{D}}{\mathcal{O}}$ departments. Page 54 of the BMA fees guide has been revised to take account of the new fees $\overrightarrow{\hat{\sigma}}$ for colliery emergencies and the fees payable 3 by the National Society for the Prevention of Cruelty to Children (16 April, p 1298). BMA members who require a copy are asked to send a stamped addressed envelope, quoting their current BMA membership number and the reference "Fees 103."

Changes in the law on drinking and driving-continued from page 1455

system at its worst. When the original Act was introduced in 1967 the courts blatantly opposed its application. It was necessary to go to the Court of Criminal Appeal to obtain a ruling that a suspect was not allowed to insist on blood being taken from his penis and as far as the House of Lords to exclude the big toe. Convictions were quashed on the basis that police officers who had stopped drivers with blood alcohol concentrations equivalent to a bottle of distilled spirits had no reason to suppose at the time that the drivers had alcohol in their bodies. A former Lord Chief Justice quashed the conviction of a driver who had deliberately taken alcohol after a road accident in order to confuse the estimation of blood alcohol (the "hip flask" dodge) on the grounds that it was perfectly normal to take alcohol after any accident in order to treat the "shock." It did not seem to have occurred to the learned chief justice that alcohol is just about the worst thing drivers can take after motor vehicle accidents, in which head injuries pose such difficult problems of diagnosis and treatment. This attitude, of course, sums up the attitude of the courts to what has been $\bar{N}$ one of the most important pieces of public health legislation $\mathrm{N}$ this century. Much will therefore depend on the attitude of $\omega$ the courts to this latest attempt to control drinking driving accidents. If the courts decide to obstruct it the driving popula- $\bigcirc$ tion will draw its own conclusions and the police will become $\mathbb{D}$ discouraged, as happened following the 1967 Act. If the courts decide to enforce the new provisions the perception of the risk of being caught will rise appreciably and we should see some $\overrightarrow{\mathbb{D}}$ impressive reduction in casualty figures during and after peak drinking periods. In consultation with the legislation on compulsory wearing of seat belts this legislation could save many people an involuntary trip to the accident and emergency department.

\footnotetext{
1 Transport Act 1982. London: HMSO, 1982.
} 